ppi $201502 Z U 4645$

Esta publicación científica en formato digital es continuidad de la revista impresa ISSN-Versión Impresa 0798-1406 / ISSN-Versión on line 2542-3185Depósito legal pp $197402 Z$ U34
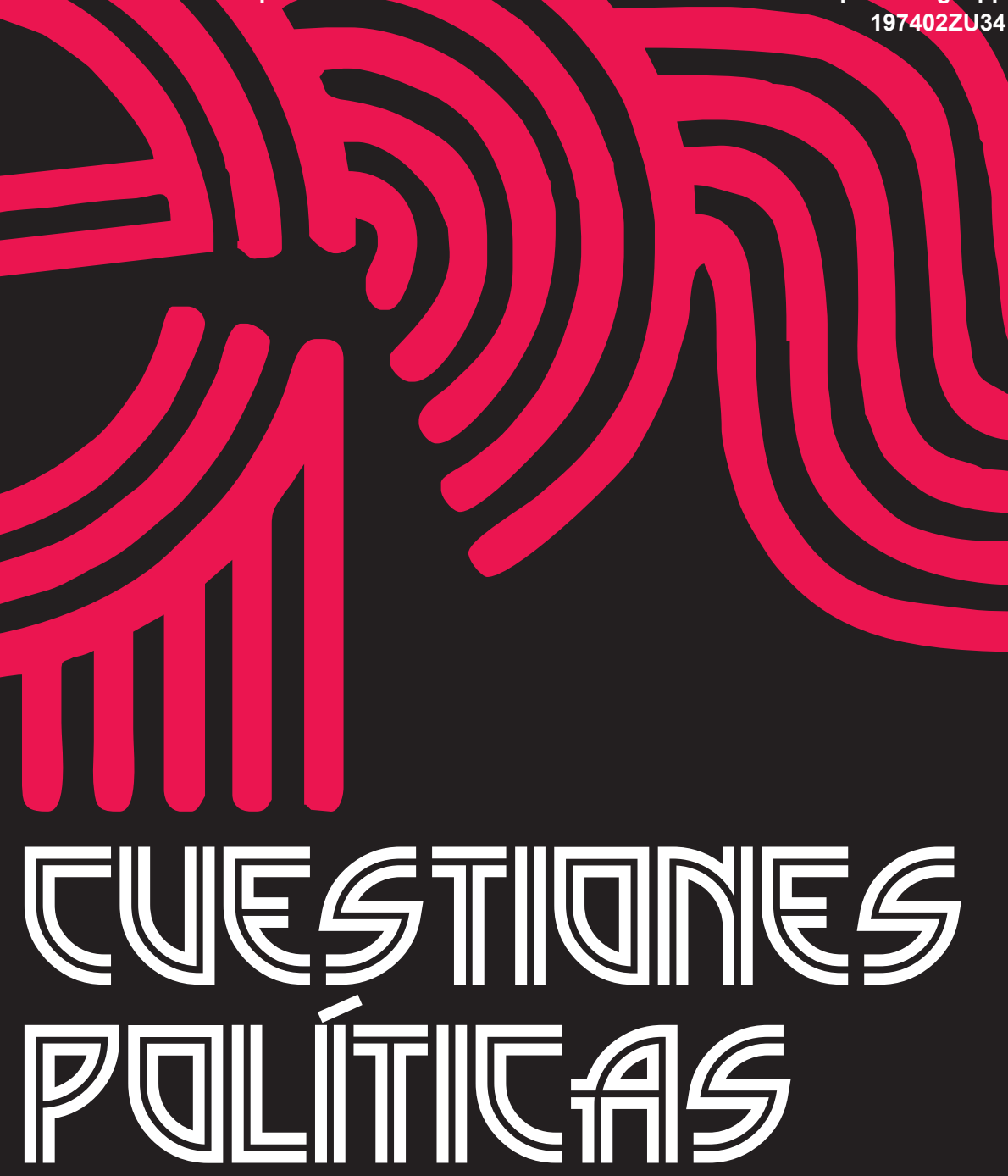

Instituto de Estudios Políticos y Derecho Público "Dr. Humberto J. La Roche" de la Facultad de Ciencias Jurídicas y Políticas de la Universidad del Zulia Maracaibo, Venezuela
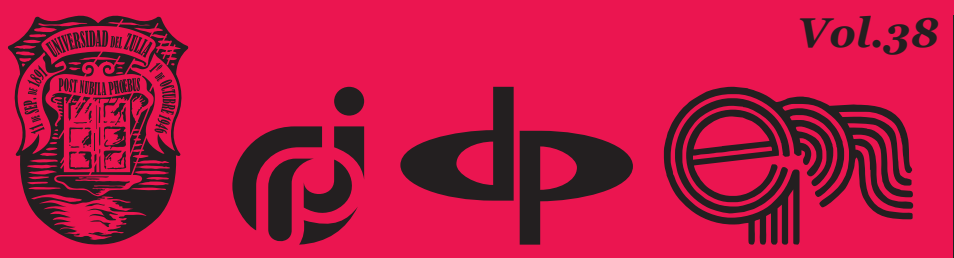

$N^{\circ}$ Especial 2da Parte 2020 


\title{
Criminal Liability of Medical Profecionals Negligience: Comparative Analysis
}

\author{
DOI: https://doi.org/10.46398/cuestpol.382e.19
}

\author{
Kateryna Danchenko * \\ Olga Taran **
}

\begin{abstract}
The purpose of this article is to study the criminal liability of medical professionals in cases of suspension, in accordance with jurisprudence in Ukraine, the European Union and the United States of America (USA). He made the comparative method. According to the investigation, the number of criminal proceedings in Ukraine by the authority and misconduct of medical doctors is about 2\% per population, my figure that rises to 30\% in Europe and is the stable yes in the US and is $28 \% .32 \%$. The main objective of the article is often area identify specializations in the medical office occurs with the mayor based on Ukrainian jurisprudence (data from Ukraine's only state judicial decision register from 2016 to 2019). In addition, the study analyses the impact of the main influences on the ability of medical professionals for their professional functions. From counting the results show that surgeons, gynecologists, paramedics, and anesthesiologists are the most prone to deviation and medical error. Key proposed criteria have been proposed as medical errors differ from medical writing.
\end{abstract}

Keywords: compensation; medical error; professional negligence; criminal liability; rule of law.

\footnotetext{
* Ph.D. of Juridical science, Assosiate professor of the Department of private and public law, Precarpathian Faculty (Ivano-Frankivsk) National Academy of Internal Affairs, Ivano-Frankivsk. ORCID ID: https://orcid.org/oooo-00o3-4489-4619. Email: nagornakate@yahoo.com

** Ph.D. of Juridical science, Assosiate professor of the Department of private and public law, Precarpathian Faculty (Ivano-Frankivsk) National Academy of Internal Affairs, Ivano-Frankivsk. ORCID ID: https://orcid.org/oooo-0001-6302-2176. Email: olpuch.taran@gmail.com
} 


\section{2 \\ Kateryna Danchenko y Olga Taran \\ Criminal Liability of Medical Profecionals Negligience: Comparative Analysis \\ Responsabilidad Penal de los Profesionales Médicos Negligencia: Análisis Comparativo}

\section{Resumen}

El propósito de este artículo es estudiar la responsabilidad penal de los profesionales médicos en casos de negligencia, con arreglo en la jurisprudencia de Ucrania, la Unión Europea y los Estados Unidos de América («EE.UU.»). Se hizo del método comparativo. Según la investigación, el número de procesos penales en Ucrania por negligencia y mala conducta de los profesionales médicos es de aproximadamente el $2 \%$ por población, mientras que esta cifra sube al 30\% en Europa y se mantiene estable en los EE. UU., y se sitúa entre el 28\%. al 32\%. El objetivo principal del artículo es identificar áreas de especializaciones donde la negligencia médica ocurre con mayor frecuencia en base a la jurisprudencia de Ucrania (los datos del único registro estatal de decisiones judiciales de Ucrania de 2016 a 2019). Además, el estudio también analiza el impacto de las principales influencias sobre la capacidad de los profesionales médicos para desempeñar sus funciones profesionales. DE concluye que los resultados muestran que los cirujanos, ginecólogos, paramédicos y anestesiólogos son los más propensos a la negligencia profesional y al error médico. Se han propuesto criterios clave según los cuales el error médico se diferencia de la negligencia médica profesional.

Palabras clave: indemnización; error médico; negligencia profesional; responsabilidad penal; norma jurídica.

\section{Introduction}

The Law 2168 - VIII "On State Financial Guarantees of Public Health Care" in Ukraine came into force in 2018. Starting in January 2018, the Ministry of Health has begun to introduce the reform in the Ukrainian health system. As such, the National Health Service of Ukraine was created on 30 March 2018, which is the central executive body that implements the basic principle of the reform - "money follows the patient". Therefore, the first step was taken to introduce health coverage, which should put an end to the existing prejudice old medical system, according to which, $49 \%$ of medical expenses are paid out of patient's pocket (National Health Service of Ukraine, 2018). Despite the fact that the health coverage has not become universal, network of private clinics is actively developing in Ukraine. Such expansion of health care facilities should help to improve the quality and level of health care in the country. 
The factor of financial compensation for the health care providers should not be overlooked either. According to the research, a doctor's visit in a private clinic costs anywhere from \$6 USD to 12\$ USD per hour, while the minimum wage of a doctor in a public hospital is \$240 USD per month. Another not less important factor is the hours of operations. The $80 \%$ of public hospitals accept patients only the first part of the day, between 8:00 am and 1:00 pm, when the private clinics offer their services from 2:00 pm to 7:00 pm. In addition, on average a doctor in a public clinic attends from 10 to 12 patients per day with one lunch break, a doctor can allocate on average 15 minutes per patient (including data entry and patient complaint description). The absence of regulated policies and the lack of efficient operating system in clinics and hospitals makes it extremely difficult to provide high-standard medical care. Due to those conditions, the probability of medical professionals making errors in diagnosis or treatment increase tremendously.

That's why the aim is to identify the core specializations for which cases of malpractice by a healthcare professional are most frequently raised, based on the jurisprudence of Ukraine, some countries of European Union, and the US. By investigating the correlation between medical liability, medical error, and the observance of rights and freedoms of a person and a citizen in the field of providing high quality medical care.

\section{Methodological Framework of the Research}

Having taken the data from the Unified State Register of Judgments of Ukraine from 2016 to 2019 and separated the cases that were brought against medical professionals, we analyzed what type of claims were resolved, and which were justified by the court. We have grouped the received data according to specialty of medical professionals. Based on the information received, we have been able to identify in which areas of medical practice negligence occurs most often and which criminal or civil penalties have been imposed by the Ukrainian courts of law for such crimes.

By comparing this data with data from various sources from the European Court of Human Rights and the US, we have identified groups of medical professionals who were prosecuted for negligence/misconduct most often.

A dialectical method of cognition has been applied in the process of investigating these issues. The historical method of research has allowed us to consider the stages of formation of views on such a phenomenon as misconduct by medical or pharmaceutical professionals and a medical error. The method of analysis of sociological data was used to investigate 


\section{Kateryna Danchenko y Olga Taran \\ 254 \\ Criminal Liability of Medical Profecionals Negligience: Comparative Analysis}

problems existing in society from the point of view of medical law in general and criminal law in particular. The comparative method was used to study the norms of foreign legislation on selected topics.

\section{Review of the Literature}

According to the data of the Unified State Register of Judgments of Ukraine: in 2015, eight criminal and/or civil charges were made against medical practitioners, one of which was acquittal; in 2016, six charges were reported (four of which were made under Part 2 of Article 140 of the Criminal Code of Ukraine) and three of them were acquittals (one of which under Part 2 of Article 140 of the Criminal Code of Ukraine); in 2017, six convictions were made one of which was acquittal; in 2018, seven charges were issued, two of which resulted in acquittals; in 2019, seven convictions were made against medical professionals, two of those were justifiable (Figure 1) (The only state register of court decisions, 2016-2019).

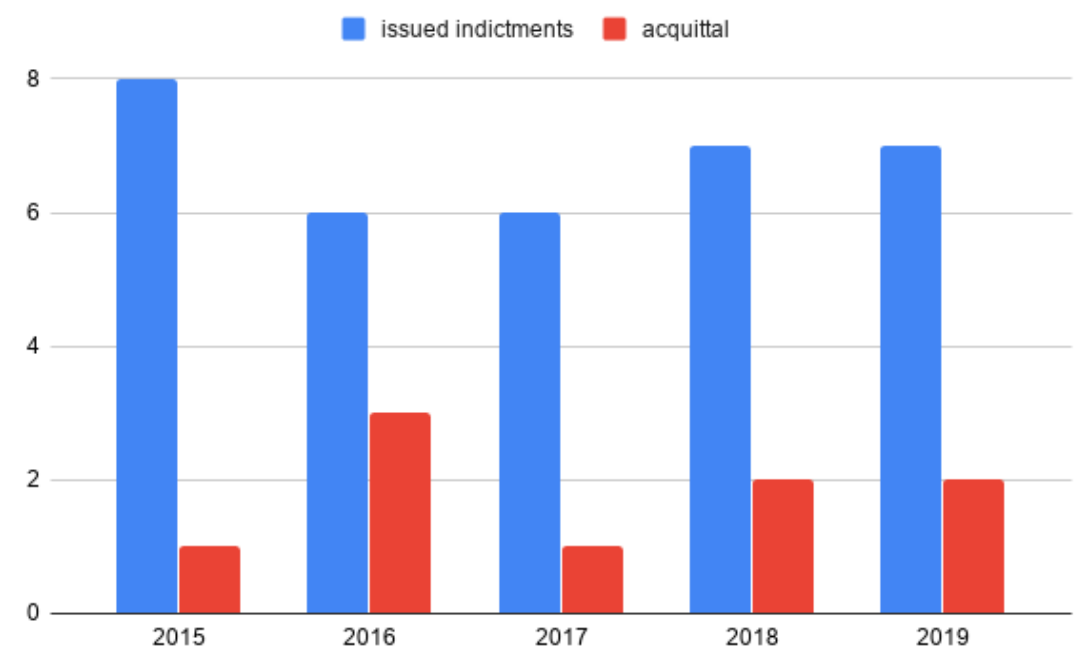

Figure 1. Statistics of indictments for medical error in Ukraine according to the Unified State Register of Judgments from 2016 to 2019. 
It should be noted that these factors were not considered to mitigate the criminal responsibility of a health care professional for their misconduct.

The situation is quite different in the countries of European Union where healthcare coverage has become universal, but a lot of people are still concerned about the quantity of medical errors and negligence/misconduct of medical professionals. Due to the expending case law against negligence/ misconduct of medical professionals, the cost of healthcare coverage in many European countries is increasing rapidly (Faure and Koziol, 2001).

However, health care system is facing a serios issue in the nearest future which involves the lack of highly trained medical professionals in a public sector due to the limited budget. Which in fact will resolve in slimmer chances for a general public to receive a high-quality healthcare. The evolution in criminalizing the liability of medical professionals for their misconduct and case-law expansion of understanding medical errors may cause the reduction of health care facilities which will lead to a high mortality rate. As a deficit in health care facilities will forth people to pay from their pockets and go to private clinics/hospitals or they will be due for a long wait at public health care facilities, due to the lack of staffing.

The author would like to draw your attention to quite interesting practice that has been currently used by the US government. While the US protects the patients' rights it does not neglect the rights of medical professionals. This is evidenced by so-called "Apology Law", which is widely used in more than 30 states so far, helping the two parties to reach an agreement faster and resolve the dispute through mediation. However, as noted by Benjamin J. McMichael, R. Lawrence Van Horn \& W. Kip Viscusi, from 2004 till 2011, the claims against $4 \%$ of physicians have been lodged annually for misconduct in both jurisdictions. A fewer lawsuit has been made in states where there is no Apology Law practice. Therefore, it is arguable that the socalled Apology Law is sufficiently legislated to protect medical professionals from widespread jurisprudence of increasing standards of care quality (McMichael et al., 2019).

According to our analysis the implemented criminal liability of medical professionals is in a desperate need for improvement. Medical practitioners are humans first and there is always a room for an error. The high standards of medical practice, which are now widely commented on by judicial practices not only in Ukraine but also in the world only aggravate the fear of being indicted to criminal responsibility, which can lead to a shortage of healthcare professionals. Therefore, it is necessary to develop a new or alternative healthcare system. 
Kateryna Danchenko y Olga Taran
256 Criminal Liability of Medical Profecionals Negligience: Comparative Analysis

\section{Results}

Analyzed data from the Unified State Register of Judgments from 2016 to 2019, we came to the conclusion that obstetric gynecologists were most often indicted (12 cases out of 40 were initiated against obstetrician gynecologists, 4 from which were justified sentences with imprisonment up to three years and two sentences with disabling of medical activity for a term of up to five years). According to Part 1 of Article 140 of the Criminal Code of Ukraine (failure or misconduct of medical or pharmaceutical professionals in the result of negligent or dishonest treatment if it caused the grave consequences for a patient) and under Part 2 of Article 140 of the Criminal Code of Ukraine (the same act if it caused grave consequences to a minor) (Criminal Code of Ukraine, 2001) the defendant was most severely punished in 2016.

The court imposed a sentence to three years imprisonment and two years' of medical license suspension. Surgeons follow (eight cases out of 40 have been initiated against surgeons, two of which were exculpatory sentences and six were indictments; the most common punishment is deprivation of right to hold posts and disabling of medical activity for up to five years). While, in Ukraine in general: obstetricians-gynecologists $33 \%$; surgeons - 20\%; anesthesiologists - 12\%; ambulance workers - 7.5\%; paramedics - $5 \%$; medical assistants - $5 \%$, other specialties - $17,5 \%$ (in total, one criminal case conducted in different specialties, except the above) of the total number of cases on which the convictions and acquittals were made between 2016 and 2019 and one case with information on which is confidential (Figure 2). 


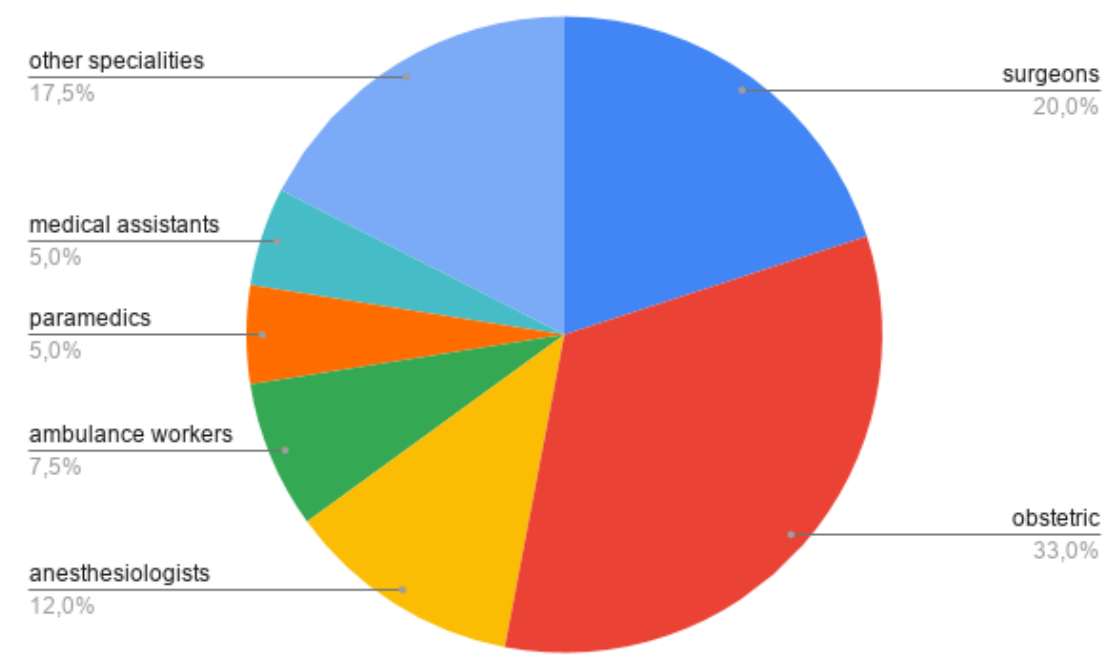

\section{Figure 2. Distribution of convicts for medical error in Ukraine by their medical specialty according to the Unified State Register of Judgments from 2016 to 2019.}

Based on a study conducted by Marco Bonetti, Pasquale Cirillo, Paola Musile Tanzi, Elisabetta Trinchero in 15 regions of Italy from 2001 to 2012, the most frequently raised are claims of medical errors and medical professionals' negligence of such specialties as: surgery - 20, 86\%; orthopedics - 11.08\%; ambulance workers - 10.88\%; general medicine - 10.11\%; gynecology - 6,72\%; anesthesia - $1.87 \%$; other specializations $12,58 \%$; not classified $-14.32 \%$ and information on which is not available - $11.58 \%$ of the total number of 38125 cases were initiated against medical professionals, which generally tells us that on average 3466 cases are initiated annually (Bonetti et al., 2016). Based on a study conducted by Burçin Gürbeden and Erdem Özkara in Turkey, it is possible to identify the most frequently prosecuted medical professions: $19.9 \%$ of emergency workers; obstetrics and gynecology - 16\%; anesthesiology - 9,4\%; surgery - 8.3\%; pediatrics - 4.4\% of the total number of 105 cases initiated in from 2010 to 2014 (Gürbeden and Özkara, 2018).

Become familiar with the scholarly literature of David M. Studdert, Marie M. Bismark, Mishelle M. Mello, etc. in the US, concerning the practice of prosecuting medical professionals during 2005 and 2014, made it possible to distinguish the specialties for which the most often criminal charges were made: therapy - 15\%; gynecology - $13 \%$; surgery - $12 \%$; family 


\section{Kateryna Danchenko y Olga Taran \\ 258 Criminal Liability of Medical Profecionals Negligience: Comparative Analysis}

medicine - 11\%; orthopedics - $7 \%$; radiology - 6\%; ambulance workers - $5 \%$; anesthesiology - 4\%; other specializations - 27\%, the total number of 54054 cases of professional negligence (Studdert et al., 2016).

The analysis showed that infringement proceedings are being initiated (in all the countries under consideration), regarding the professional's failure to perform his/her professional duties, including: surgery, gynecology, emergency, anesthesia (Figure 3).

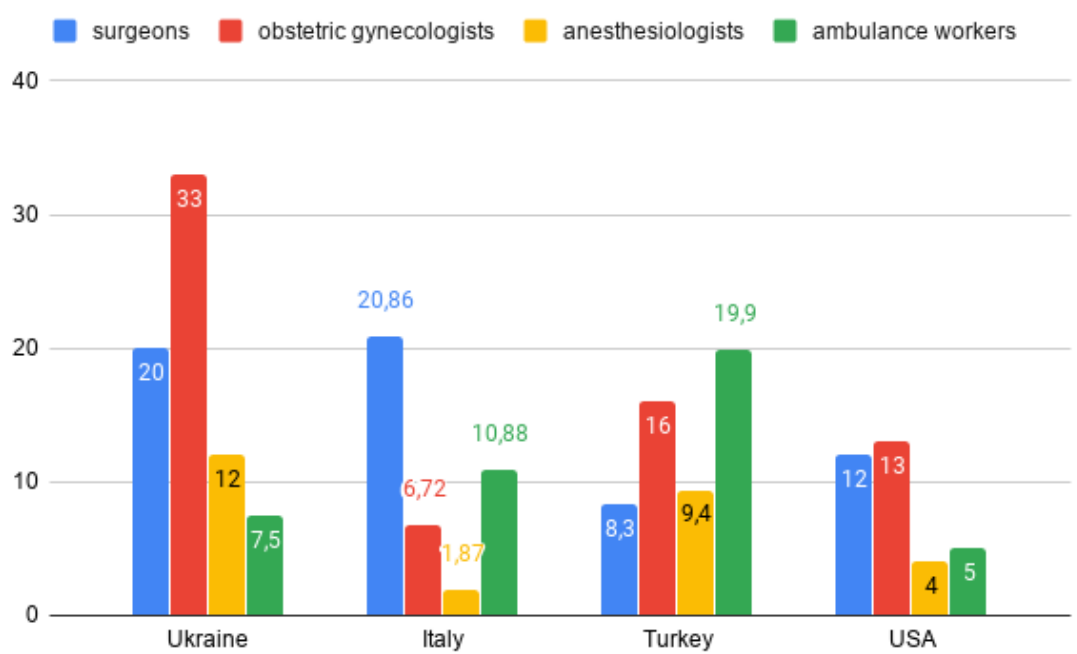

Figure 3. Distribution of sentences among surgeons, gynecologists, anesthesiologists and ambulance workers in Ukraine, Italy, Turkey, and USA.

In nowadays world, quite often medical professionals are guided by the fear of being criminally accountable for their practice by takin extra precautions while diagnosing patients, sometimes which result in unnecessary and extremely broad diagnosis. Which in fact does not reduce patients' claims. Medical practitioners in areas of specializations where negligence takes place most frequently are the areas that possess high level of stress. Those are surgeons, gynecologists, paramedics, and anesthesiologists. After all, those specializations require enormous among of focus, self-control, and outstanding decision-making skills under extremely difficult circumstances. Therefore, those medical practitioners 
appear at particularly high risk, as evidenced by the high rate of burnout and the alarming consequences in both their personal lives and professional behavior.

By taking all those factors into consideration it is truly clear that at times it is extremely difficult for medical professionals to make sound judgments. That is why it is important to understand when a healthcare professional becoming a suspect or convicted felon the nature of their work and the emotional distress caused by it should not be overlooked. According to the scientific literature professions that are in a high risk of mental and emotional burnout are as follow (officials, operators of technical systems, etc.), forensic scientists (in particular, L.P. Brych, M.S. Greenberg, V.A. Navrotsky, R.I. Mikheyev, N.A. Orlovskaya, T. Yu. Tarasevich, and others) emit a special (professional) conviction, which determines the person's state of a particular profession, capable of adequate behavior during emotional and mental distress. P.S. Dagel, in support of this view, pointed out that the realization of the idea of special condemnation would make the concept of a special subject in relation to "technical" crimes more meaningful if the psychophysical qualities of a person were taken into account (Dahel, 1978).

In this way, emotional and mental distress affect the ability to make sound judgment and to manage professional performance of duties for medical or pharmaceutical practitioners. Emotional and mental distress is a condition of a human body in mental overstrain due to hard work (Teslitskiy, 2004). Which is of two types: mental stress (a state of mobilization that is within the optimal level of alertness) and mental tension (a negative emotional reaction that occurs in an unusual, new or threatening situation), which cause emotional-sensory or emotional-intellectual violation (Blok, 1980). A significant role in emergence, development and course of mental tension is manifested in adverse factors, as well as in difficult conditions of life. The onset of a disease can be turbulent, sometimes gradual, unnoticeable to others (chronic insomnia, significant weakening of the body, etc.).

However, even in this case, processes of perception of outside world are disturbed, thinking disorders are observed. Psychiatrists say that the prolonged effect of mental tension can cause a variety of psychogenic diseases in people - neuroses, psychoses or psychopathies, which are generally characterized by excessive excitability, irritability, visual hallucinations, as well as psychopathic conditions, which develop in the course of consciousness, temporary disorders of mental activity (Chupryna, 2014; Kuznetsov and Cherniavskyi, 1993).

According to I.M. Fil, in cases where medical professional negligence caused by emotional and mental distress of practitioners while maintaining the ability to realize their actions (inaction) and criminal liability should be resolved within careless guilt (criminal overconfidence or criminal negligence) or case. However, in cases where a medical or pharmaceutical 
professional is unable to realize their actions (inactivity) or to manage them due to a temporary disorder of mental activity, there is not a special conviction, but a lack of conviction in its traditional sense (Fil, 2018).

The term "medical professional's defect" encompasses all adverse actions committed by a variety of healthcare professionals (such as technical staff) regardless of the fault form. That is why the complexity of proving the presence of a criminal offense in the field of medical activity in connection with so-called "dynamics of clinical picture", the possibility of concealment or lack of facts fixation that are of legal importance for determining the guilt of a specialist, the complexity of assessing the reaction of human body under certain conditions (Rotkov and Chuprova, 2018).

It may result in inaccurate diagnosis, poor treatment of a patient, organization of medical care, which could lead to an unfavorable result of medical intervention (Kulchynska and Uspenska, 2013). Therefore, we believe it is important to identify the key criteria that will separate a medical error from medical professionals' negligence. However, at times it is extremely difficult to differentiate those two. First, it is necessary to evaluate the doctor's actions to determine their "integrity", which requires involvement of a special expert commission (for example, in Israel such a committee includes psychologists, lawyers, doctors and representatives of public and religious organizations). Secondly, doctors may be indicted both on a general basis and for offenses related to professional activity of medical professionals, as well as, as an official, when a doctor is entrusted with the performance of organizational, administrative and administrative functions in a medical facility (Pastushenko, 2009).

Investigation of criminal offenses in the provision of health care (medical service) is associated with a number of complex problems - the peculiarity of the subject of proof, the lack of proper knowledge of the specific nature of such categories of pre-trial investigation bodies, which in turn affects the analysis and evaluation of the collected information (Danchenko and Hereljuk, 2020; Danchenko and Taran, 2020). Thus, in each of our investigated cases, on average, $10 \%$ of those cases are information about missing or restricted access. And this in turn does not give us a chance to assess fully the harm caused to a person by medical professionals and deliberately separating him/her from the harm caused by medical professionals during performing their professional duties, which led to misinterpretation of symptoms and, as a result, a medical error. Medical malpractice likewise needs to transition to a new model that is consistent with the modern era of patient-centered care (Stamm et al., 2015).

All this proves the great need for development of a single standard of medical practice that would best meet the patient's needs and protect the medical professionals' interests, since the desire for reinsurance also leads to high cost of healthcare coverage, if the pressure on medical professionals was not so great from the legal perspective. 


\section{Conclusion}

In our comparative analysis of the criminal liability of medical professionals based on their negligence, we were able to identify four areas of specializations where medical negligence takes place most frequently. Those are surgeons, gynecologists, paramedics, and anesthesiologists. We have concluded that these specializations are most often performing their duties under extremely stressful conditions and therefore, we consider it necessary to develop a special mechanism for bringing to justice medical practitioners in such specializations, taking into account the extremely challenging nature of their work and the emotional and mental distress caused by it. Based on the analysis of all the cases concerning in given categories of medical professions, it would be appropriate to create an algorithm that would allow to calculate when and under what circumstances medical practitioners in those four areas of practice are most prone to the professional negligence and medical error. In our opinion this algorithm will help to reduce the psychological (emotional and mental) pressure on medical professionals, reduce claims, and improve the operation of healthcare facilities.

\section{Bibliographic references}

BLOK, Vincent. 1980. "Levels of wakefulness and attention" In: Experimental psychology. Vol. 3. No. 121. Available online. In: http://psychologylib. $\mathrm{ru} / \mathrm{books} /$ item/foo/soo/zoooooo3/sto21.shtml. Consultation date: 14/09/2019.

BONETTI, Marco; CIRILLO, Pasquale; MUSILE TANZI, Paola; TRINCHERO, Elisabetta. 2016. "An Analysis of the Number of Medical Malpractice Claims and Their Amounts” In: Plos One. Vol 11, No. 4. Available online. In: e0153362. doi: https://doi.org/10.1371/journal.pone.0153362. Consultation date: 14/09/2019.

CHUPRYNA, Olga. 2014. "Causes of mental disorders and diseases. Symptomatology of mental illness" In: National academy of internal affairs. Available online. In: www.naiau.kiev.ua/files/kafedru/ksm/ lectures/lekc8-smp.doc. Consultation date: 14/09/2019

CRIMINAL CODE OF UKRAINE. 2001. Verkhovna Rada of Ukraine, Ukrania. April 5, 2001. No. 2341-III. Available online. In: https://zakon.rada.gov. ua/laws/show/2341-14. Consultation date: 14/09/2019 (In Ukrainian). 
DAHEL, Plehan. 1978. "Negligent crimes (general characteristic of a negligent crime in the field of the use of technology)" In: Problems of combating criminal negligence. No. 2, pp. 31-40.

DANCHENKO, Kateryna; HERELJUK, Christina. 2020. "Failure or improper performance by a medical or pharmaceutical professional of their professional duties" In: Juridical scientific and electronic journal. Available online. In: doi: https://doi.org/10.32782/2524-0374/20201/50. Consultation date: 14/09/2019 (In Ukrainian).

DANCHENKO, Kateryna; TARAN, OIga. 2020. "Ensuring the right to transplantation of persons with disabilities of psychology, behavior and psychological development" Constitutional state. Available online. In: doi: https://doi.org/10.18524/2411-2054.2020.37.201499. Consultation date: 14/05/2020 (In Ukrainian).

FAURE, Michael; KOZIOL, Helmut. 2001. "Cases on Medical Malpractice in a Comparative Perspective” In: Tort and Insurance Law. Available online. In: doi: https://doi.org/10.1163/157365102X00136. Consultation date: 14/05/2020.

FIL, Irina. 2018. "Criminal legal and criminological response to the inadmissible execution of professional obligations by medical or pharmaceutical employees" In: The Institute of State and Law. V.M. Koretsky National Academy of Sciences of Ukraine. Kyiv, Ukraine.

GÜRBEDEN, Burçin; ÖZKARA, Erdem. 2018. "Assessment of cases with medical malpractice claims which's autopsies were performed in Council of Forensic Medicine İzmir Group Chairmanship between 2010-2014" In: Romanian Society of Legal Medicine. Vol 26, No. 2, pp. 112-119.

KULCHYNSKA, Yulia; USPENSKA, Hanna. 2013. "Medical errors as a legal category and criteria for their separation from crimes" In: Scientific journal of National Pedagogical Dragomanov University. Available online. In: http://enpuir.npu.edu.ua/handle/123456789/25848 Consultation date: 14/05/2020. (In Ukrainian).

KUZNETSOV, Valerii; CHERNIAVSKYI, Volodymyr. 1993. Psychiatry. Textbook. Zdorovia. Kyiv, Ukraine. (In Ukrainian).

MCMICHAEL, Benjamin J; VAN HORN, R. Lawrence; VISCUSI, W. Kip. 2019. "“Sorry” Is Never Enough: How State Apology Laws Fail to Reduce Medical Malpractice Liability Risk” In: Stanford Law Review. Available online. In: https://scholarship.law.vanderbilt.edu/facultypublications/1086/. Consultation date: 14/05/2020 
NATIONAL HEALTH SERVICE OF UKRAINE. 2018. Report of National Health Service of Ukraine for 2018. Available online. In: https://nszu. gov.ua/storage/files/zvit-2018.pdf. Consultation date: 09/06/2019. (In Ukrainian).

PASTUSHENKO, Svitlana. 2009. "Peculiarities of the composition of the crime provided in Article 140 (1) Criminal Code of Ukraine" In: Bulletin of the Academy of Advocacy of Ukraine. Vol 1, No. 14, pp. 296-299. (In Ukrainian).

ROTKOV, Andrey; CHUPROVA, Antonina. 2018. "Improper performance by a medical worker of his professional duties as a sign of a crime under part 2 of article 109 of the Criminal code" In: Legal Science and Practice. Available online. In: doi: 10.24411/2078-5356-2018-10444. Consultation date: 09/06/2019. (In Russian).

STAMM, Jason A; KORZICK, Karen A; BEECH, Kristen; WOOD, Kenneth. E. 2015. "Medical malpractice: reform for today's patients and clinicians" In: The American Journal of medicine. Available online. In: doi: https://doi. org/10.1016/j.amjmed.2015.08.026. Consultation date: 09/02/2020.

STUDDERT, David M; BISMARK, Marie M; MELLO, Michelle M; SINGH, Harnam; SPITTAL, Matthew J. 2016. "Prevalence and Characteristics of Physicians Prone to Malpractice Claims" In: The New England Journal. Available online. In: doi: https://doi.org/10.1056/NEJMsa1506137. Consultation date: 09/02/2020.

TESLITSKIY, Ilia. 2004. Innocent harm on a psychophysiological basis in criminal law. Stavropol, Russia. $167 \mathrm{p}$.

THE ONLY STATE REGISTER OF COURT DECISIONS. (2016-2019). Available online. In: https://reyestr.court.gov.ua/. Consultation date: $05 / 22 / 2020$ 

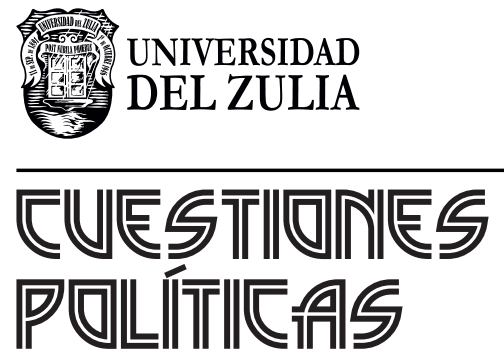

Vol.38 NEspecial

Esta revista fue editada en formato digital y publicada en diciembre de 2020, por el Fondo Editorial Serbiluz, Universidad del Zulia. Maracaibo-Venezuela 